\title{
KOMUNIKASI MITIGASI BENCANA OLEH BADAN GEOLOGI KESDM DI GUNUNG API MERAPI PROV. D. I. YOGYAKARTA
}

\author{
Titan Roskusumah \\ Badan Geologi Kementerian Energi dan Sumber Daya Mineral
}

\begin{abstract}
ABSTRAK
Penelitian ini bertujuan untuk menganalisis pemahaman mengenai komunikasi mitigasi bencana oleh masyarakat sekitar Gunung Merapi, upaya dan pola komunikasi yang dilakukan Badan Geologi terkait kepercayaan lokal masyarakat. Metode yang digunakan dalam penelitian ini adalah metode kualitatif dengan paradigma konstruktivisme menggunakan teori interaksionisme simbolik dan jenis studi kasus. Masyarakat Desa Umbulharjo Kecamatan Cangkringan Kabupaten Sleman Provinsi D.I. Yogyakarta yang merupakan masyarakat yang tinggal di sekitar Gunung Merapi menjadi subjek dari penelitian ini. Data penelitian diperoleh melalui wawancara mendalam dan studi pustaka. Hasil penelitian menunjukkan bahwa masyarakat sekitar Gunung Merapi memahami inti dari Komunikasi Mitigasi Bencana sebagai sumber pemberian informasi mengenai keadaan Gunung Merapi dan sumber pemberian informasi mengenai tindakan yang harus dilakukan oleh masyarakat. Peningkatan keikutsertaan masyarakat dan peran Juru Kunci merupakan upaya Badan Geologi dalam melakukan Komunikasi Mitigasi Bencana. Pola Komunikasi Mitigasi Bencana yang dilakukan Badan Geologi KESDM terkait kepercayaan lokal masyarakat sekitar Gunung Merapi terdiri dari dua jenis yaitu terstruktur dan melalui media. Dalam rangka meningkatan kapasitas masyarakat dalam menghadapi dan menanggulangi bencana geologi untuk menghindari ketidakselarasan dalam penerimaan informasi, Komunikasi Mitigasi Bencana perlu dikaji lebih dalam oleh Badan Geologi KESDM. Badan Geologi KESDM diharapkan dapat pula meningkatkan frekuensi sosialisasi dan simulasi bencana langsung pada masyarakat pada level bawah, tidak hanya mengundang perwakilan dari aparat pemerintah saja. Selain itu Badan Geologi sebaiknya melibatkan Juru Kunci Merapi dengan memberikan pelatihan khusus mengenai istilah-istilah teknis kebencanaan sehingga Juru Kunci bisa menjadi agen sosialisasi bagi masyarakat.
\end{abstract}

Kata-kata kunci: Komunikasi mitigasi bencana, Badan Geologi, Gunung Merapi, Yogyakarta

\section{DISASTER MITIGATION COMMUNICATION BY THE GEOLOGY AGENCY OF ENER- GY AND MINERAL RESOURCES MINISTRY IN MERAPI VOLCANO IN YOGYAKARTA PROVINCE}

\begin{abstract}
This research which purposes are to analize how local people around Mount Merapi understand about Communication Of Disaster Mitigation, to study the effort, and to look at the Pattern of Communication On Disaster Mitigation done by Geological Body in relation to the belief of local people. A method used in this research is qualitative method with constructivism paradigm, uses theory of symbolic interactionism and case study. The people in Umbulharjo Village, Cangkringan District, Sleman Regency, D.I. Yogyakarta Province whish lives around Mount Merapi is the subject of the research. Research data was collected through depth interview and literature research. The result of this research shows that the local people at Mount Merapi understand about Communication Of Disaster Mitigation as information provision concerning Mount Merapi status and what the people have to do about it. Improve participation of local people and the role of Juru Kunci are the efforts of Geological Body in Communication Of Disaster Mitigation. Pattern of Communication On Disaster Mitigation done by Geological Agency in relation to the belief of local people of Mount Merapi is categorized in two communication patterns, structured and through media. In order to improve the people capability in facing and mitigating geological disaster and to avoid inconsitency on information being received, Communication Of Disaster Mitigation need to evaluate by Geological Body of Ministry of Energy and Mineral Resources. It is hoped that Geological Body Ministry of Energy and Mineral Resources can increase the frequency of information dissemination and disaster mitigation simulation directly to the people on the lowest level not only by inviting the government representative. Also Geological Body should try to have Juru Kunci of Merapi involved by giving certain training about disaster terms so that Juru Kunci can become information agent to the people.
\end{abstract}

Keywords: Disaster mitigation communication, geological body, Mount Merapi, Yogyakarta

Korespondensi: Titan Roskusumah, M.Si., Badan Geologi Kementerian Energi dan Sumber Daya Mineral, Jl. Diponegoro No.57 Bandung, Email: titan_ros@yahoo.com 


\section{PENDAHULUAN}

Komunikasi Mitigasi Bencana Letusan Gunung Api Merapi (selanjutnya disebut Gunung Merapi) yang dilakukan oleh Pemerintah, dalam hal ini Badan Geologi KESDM adalah menyampaikan segala informasi kebencanaan Gunung Merapi kepada masyarakat seluruh Indonesia, terutama masyarakat sekitar Gunung Merapi Yogyakarta. Langkah awal yang diambil dalam upaya penanggulangan bencana gunung api adalah mengenali karakteristik bencana sehingga mampu dipilih serangkaian tindakan yang tepat dalam penanganan bencana baik sebelum kejadian, saat dan pasca kejadian.

Komunikasi mitigasi bencana merupakan tindakan yang harus menjadi prioritas utama untuk dipikirkan dan dilakukan kepada masyarakat yang bertempat tinggal di wilayah rawan bencana. Bagaimana pemerintah maupun pihak terkait menyiapkan masyarakat yang tinggal di wilayah rawan bencana untuk bersiap menghadapi bencana dengan cara menyampaikan informasi awal masalah tentang kebencanaan dalam hal ini bencana geologi. Komunikasi mitigasi bencana yang dilakukan Badan Geologi untuk masyarakat, bermacam-macam jenisnya. Mulai dari sosialisasi langsung, melalui media, baik itu cetak maupun elektronik maupun simulasi-simulasi teknis kebencanaan. Poin utama dari komunikasi mitigasi bencana adalah tentu saja mengungsi ketika bencana sudah terjadi.

Tidak dapat dipungkiri seringkali komunikasi mitigasi bencana menemui banyak kendala. Mulai dari skala prioritas yang dikedepankan oleh kebijakan internal yang dikeluarkan pimpinan dengan mendahulukan masalah teknis kegeologian maupun kendala dari masyarakat. Kendala bahasa, kendala pendidikan, kesadaran pribadi masyarakat untuk lebih peduli akan lingkungan tempat dia tinggal maupun adanya tantangan kepercayaan lokal yang dimiliki masyarakat, pertumbuhan penduduk yang cepat, pengalaman letusan yang tidak merata dan respon masyarakat terhadap informasi, penyuluhan dan pelatihan yang diadakan pemerintah.

Tantangan yang dihadapi dalam fenomena komunikasi mitigasi bencana di Gunung Merapi adalah ketika informasi mengenai bencana yang dimiliki oleh Badan Geologi KESDM ti- dak menjadi acuan utama bagi masyarakat sekitar Gunung Merapi. Informasi yang lebih dipercaya adalah informasi yang datangnya dari Juru Kunci Gunung Merapi dan simbol alam yang muncul dari Gunung Merapi itu sendiri. Mereka lebih memaknai bencana dari sudut pandang lain. Informasi yang sudah jelas keakurasiannya dengan menggunakan instrumen dan visual oleh para ahli kegunungapian menjadi nomor dua ketika masyarakat lebih mendengarkan anjuran Juru Kunci. Peristiwa meletusnya Gunung Merapi tahun 2010 dimana Mbah Maridjan sebagai Juru Kunci termasuk salah satu korban menjadi buktinya. Sirine dari Badan Geologi sudah berbunyi setiap jam, tetapi masih saja ada korban jiwa.

Komunikasi mitigasi bencana bisa dikategorikan sebagai komunikasi lingkungan. Dengan konteks untuk keselamatan lingkungan ketika mengantisipasi terjadinya bencana gunung meletus, komunikasi mitigasi bencana menjadi sarana untuk menyampaikan informasi penting berkaitan dengan hal-hal yang akan terjadi.

Bencana yang diteliti disini tentu saja bencana geologi.Pemahaman yang paling penting adalah memahami karakter dari bencana geologi, karena pada setiap wilayah, bencana geologi yang dihadapi berbeda-beda. Bencana geologi merupakan bencana yang diakibatkan oleh peristiwa yang disebabkan oleh alam antara lain gempa bumi, tsunami, gunung meletus, dan gerakan tanah. Perlunya upaya mengkomunikasikan pemahaman kepada masyarakat mengenai pengenalan karakteristik kawasan yang didiami apakah termasuk kawasan rawan bencana atau tidak, sehingga kerusakan dan korban jiwa dapat diminimalisir apabila terjadi bencana geologi.

Mengapa komunikasi mitigasi bencana ini diperlukan?Tentu saja karena dampak kerugian yang sangat besar mulai dari korban jiwa, infrastruktur, materi dan lain-lain.Bencana letusan gunungapi sebagai salah satu bencana geologi merupakan siklus bencana yang mendadak, tiba-tiba, tidak bisa diprediksi, belum dapat diramal kapan dan berapa besar, tidak teratur, waktu cepat dan dampak bencana lama. Meski sebetulnya semua gunung api selalu menunjukkan gejala sebelum meletus, tetap saja teknologi yang dipadu dengan kemampuan para ahli sangat terbatas sehingga tidak mampu me- 
nerjemahkan secara tepat gejala yang muncul. Kaitannya dengan bencana yang akan selalu ada itulah maka mitigasi bencana diperlukan.

Komunikasi merupakan inti keberhasilan mitigasi bencana, kesiapsiagaan, respon, dan pemulihan pasca bencana (Haddow, 2008: xvii). Kemampuan untuk menyebarkan informasi yang akurat kepada masyarakat umum, para pemangku kebijakan dan media mengurangi risiko, menyelamatkan nyawa dan harta benda dan tentunya kecepatan pemulihan. Dalam mitigasi bencana gunung meletus, komunikasi sama pentingnya dengan hal teknis lainnya. Berkomunikasi dengan masyarakat adalah tugas penting yang diemban oleh pemerintah.

Peran pemerintah sebagai ujung tombak dan pelindung masyarakat sangat diharapkan mampu mengayomi masyarakat dalam hal menghadapi bencana. Perencanaan dan pengelolaan arus informasi akan menentukan kredibilitas, kepercayaan, otoritas dan efektivitas upaya pemerintah dalam hal mitigasi bencana gunung meletus. Para pemimpin diharapkan bisa memberi ketenangan dengan informasi yang akurat untuk mengetahui apa yang harus dilakukan dan masyarakat diyakinkan bahwa pemerintah baik pusat maupun daerah merespon bencana dengan tepat.

Komunikasi mitigasi bencana merupakan komunikasi yang dilakukan dalam upaya pencegahan terjadinya bencana (Haddow, 2008: xvii). Komunikasi kaitannya dengan mitigasi bencana sangat diperlukan karena adanya kebutuhan untuk mengurangi ketidakpastian di lingkungan masyarakat sehingga dapat bertindak secara efektif. Dalam pencegahan bencana, informasi yang akurat dari pemangku kepentingan dalam hal ini pemerintah sangat diperlukan oleh masyarakat maupun lembaga swasta yang memiliki kepedulian besar terhadap peristiwa bencana tersebut. Dalam upaya untuk meminimalisir terjadinya korban jiwa atau kerugian materi.

Mengapa peneliti memilih Gunung Merapi sebagai objek penelitian? Adapun hal yang menarik perhatian peneliti karena keunikan dari karakteristik khas masyarakat sekitar Gunung Merapi yang memegang teguh kepercayaan lokal, sehingga ketika informasi mengenai bahaya gunung meletus disampaikan oleh Badan Geologi, memiliki tingkat kesulitan tersendiri. Komunikasi mitigasi bencana memiliki kend- ala karena harus menghadapi hal yang berbau mistis. Masyarakat Jawa khususnya Yogyakarta terkenal dengan Kejawennya. Selain tentunya Gunung Merapi memiliki keistimewaan berbeda dengan gunung api di wilayah lainnya, Gunung Merapi mempunyai siklus tetap dan ritme yang sudah jelas. Gunung Merapi adalah salah satu gunung api di dunia yang memiliki tipe letusan khusus yang khas yaitu letusan yang didominasi awan panas.

Popularitas Merapi selain hal-hal tersebut di atas juga karena lekat dengan unsur-unsur mitologinya. Keberadaan Kasultanan Yogyakarta dan juru kunci Gunung Merapi dalam hal ini Mas Lurah Suraksosihono atau Asih (45) yang merupakan juru kunci Gunung Merapi menggantikan ayahnya almarhum Mas Ngabehi Suraksohargo atau Mbah Maridjan, merupakan kepercayaan lokal yang menjadi daya tarik Gunung Merapi. Tradisi-tradisi Jawa yang melekat dengan aktivitas Gunung Merapi. Penelitian ini membahas bagaimana fenomena komunikasi mitigasi bencana dengan tidak mengabaikan mitos-mitos seputar Gunung Merapi bisa membantu penyampaian mengenai antisipasi meletusnya Gunung Merapi. Penduduk sekitar Gunung Merapi terbiasa dan akrab dengan letusan tapi setiap tahun selalu ada korban jiwa meski telah diberi peringatan sebelumnya. Seperti kejadian ketika tahun 2010 terjadi letusan Gunung Merapi, walaupun Pemerintah sudah menetapkan radius daerah bahaya (tidak boleh ada penduduk di radius tersebut) masih tetap banyak masyarakat yang bertahan sehingga korban pun masih berjatuhan.

Tujuan utama dari komunikasi mitigasi bencana adalah meniadakan terjadinya korban jiwa. Apabila Pemerintah tidak memperhatikan komunikasi mitigasi bencana dan hanya mengurusi masalah teknis kebencanaan, maka di masa yang akan datang kejadian tahun 2010 akan kembali terulang. Penelitian ini bermaksud membantu hal di luar teknis kebencanaan yang justru sangat vital manfaatnya ketika terjadinya bencana. Menekan jumlah korban manusia dan harta benda masyarakat yang berada di kawasan rawan bencana ketika terjadi letusan merupakan tugas sangat penting dan utama dari instansi pemerintah yang menangani bencana. Penanggulangan bencana Merapi akan berhasil baik apabila dilakukan secara terpadu dan ter- 
koordinasi. Tidak hanya dilakukan pemantauan Merapi yang menghasilkan data yang akurat dengan peralatan yang modern tapi juga harus didukung sistem peringatan dini, peralatan komunikasi yang bagus dan terutama pemahaman yang benar dan kesadaran yang kuat dari masyarakat untuk melakukan penyelamatan diri.

Komunikasi mitigasi bencana diharapkan bisa menjembatani antara kepentingan pemerintah untuk menyadarkan masyarakat dalam menyiapkan diri dan lingkungan apabila siklus rutin meletusnya gunung api Merapi terjadi. Memberikan solusi kepada kedua belah pihak apa yang terbaik yang bisa dilakukan.

Kepercayaan lokal adalah sistem religi yang dianut oleh masyarakat setempat dan diamalkan dalam kehidupan kesehariannya (Santosa, 2012: 241). Inti dari kepercayaan ini adalah mereka percaya akan adanya roh atau jiwa pada manusia, hewan, tumbuhan dan benda-benda lain di dunia. Semua yang dapat bergerak dianggap hidup dan mempunyai kekuatan gaib (roh) yang dapat berbuat baik dan buruk. Di samping itu mereka juga percaya akan adanya roh adikodrati yang paling tinggi (berkuasa) mengatur kehidupan manusia.

Di dalam sistem kepercayaan lokal, panutan masyarakat Jawa adalah dukun atau pawang (Santosa, 2012: 242). Menurut mereka, sosok inilah yang dipercaya mampu melakukan komunikasi dan interaksi dengan nilai-nilai yang dijunjung tinggi, yaitu roh-roh yang dipercaya dapat berpengaruh positif atau negatif. Selain itu dukun juga dipercaya mempunyai kekuatan batin (supranatural) tinggi sehingga mampu membantu menangani berbagai masalah individual dan sosial di lingkungannya.

Nilai-nilai kepercayaan tersebut tampak masih sangat sederhana karena hanya bersumber dari naluri, intuisi, pengetahuan, pengalaman hidup, serta interaksinya dengan masyarakat dan alam lingkungan. Formula, pola dan manifestasi nilai-nilai religi tersebut dibangun dan dibentuk sendiri berdasarkan kesepakatan masyarakat dan kesesuaiannya dengan lingkungan hidup masing-masing (Santosa, 2012: 242).

Kaitannya dengan penelitian ini, menurut kepercayaan Jawa, aktivitas meletusnya Gunung Merapi termasuk gangguan keselamatan hidup yang berasal dari alam semesta dan juga hal gaib. Fenomena gunung meletus merupakan faktor alam yang terjadi di luar jangkauan nalar dan pengetahuan manusia.

Ketika Badan Geologi melakukan tugasnya menyampaikan informasi mitigasi bencana untuk mengantisipasi meletusnya Gunung Merapi, mau tidak mau, suka tidak suka akan dihadapkan pada kenyataan bahwa masyarakat Jawa khususnya masyarakat sekitar Gunung Merapi Prov D.I Yogyakarta masih menjunjung tinggi adat istiadat mereka. Meskipun terdapat pro dan kontra mengenai berbagai ritual keselamatan yang mereka lakukan, namun banyak kalangan di Jawa masih menomorsatukan ritual tersebut.

Gunung Merapi bertalian erat dengan mitologi, kepercayaan dan filosofi masyarakat Jawa terutama masyarakat sekitar Gunung tersebut. Hal ini tergambar dengan adanya garis imajiner yang menghubungkan antara Gunung Merapi, dengan Laut Selatan (Samudera Indonesia) dengan Kota Yogyakarta sebagai titik pusat.

Gunung Merapi diliputi mitos sebagai kerajaan makhluk halus dan masyarakat percaya bahwa Gunung Merapi dijaga oleh Kiai Sapu jagad yang merupakan patih Kesultanan Mataram Islam pada masa pemerintahan Panembahan Senopati yaitu Sultan Mataram Islam yang pertama.

Begitupun dengan keberadaan juru kunci sebagai salah satu mitos di lingkungan Gunung Merapi dalam hal ini Mas Lurah Suraksosihono atau Asih (45) yang merupakan juru kunci Gunung Merapi menggantikan ayahnya almarhum Mas Ngabehi Suraksohargo atau Mbah Maridjan, merupakan kepercayaan lokal yang menjadi daya tarik Gunung Merapi.

Kesultanan di mata masyarakat Yogyakarta mempunyai derajat yang sangat tinggi dan dianggap sakral dalam tradisi Jawa. Kepercayaan masyarakat sampai saat ini adalah para raja atau Sultan mendapat wahyu langsung dari Tuhan yang diberikan sebelum naik tahta.

Dengan adanya kepercayaan dan pengkultusan tersebut, maka dalam tatanan kerajaan, siapapun dilarang keras melawan raja. Hal ini tentu saja berdampak pada juru kunci Gunung Merapi. Juru kunci Gunung Merapi merupakan abdi dalem Keraton yang dipilih dan merupakan gelar kehormatan, harus menuruti apa perintah dari Kesultanan. Sepeninggal Mbah Maridjan, setelah 30 tahun menjadi juru kunci Merapi, dipilihlah penggantinya dengan melakukan 
serangkaian tes dengan empat kriteria penilaian yaitu bidang keagamaan, kebudayaan, kekeratonan, dan kemasyarakatan dilakukan sejak awal tahun 2010. Mbah Maridjan sendiri mulai bertugas menjadi Juru Kunci Merapi menggantikan Mbah Hargo ayah kandung Mbah Maridjan yang wafat pada tahun 1977.

Tugas utama juru kunci Gunung Merapi sebagai pemimpin atau pemuka dalam ritual-ritual seputar Gunung Merapi. Ritual itu ditujukan untuk membuat keseimbangan antara kerajaan Jawa dan kekuatan besar kerajaan gaib yang dipercaya ada di Gunung Merapi. Ritual yang dimaksud adalah upacara selamatan Labuhan yang diadakan rutin setiap tahun pada hari kelahiran Sri Sultan Hamengkubuwono X yakni pada tanggal 30 Rajab (kalender Jawa) dengan memberikan sesajian ke Gunung Merapi sebagai lambang terima kasih dan memohon keselamatan kepada Tuhan bagi warga Yogyakarta. Upacara dipusatkan di dusun Kinahrejo desa Umbulharjo (BBC Indonesia, 2011). Selain itu juru kunci memberi arti yang sangat penting bagi para pendaki gunung. Juru kunci biasanya memberikan apa saja pantangan saat mendaki, memberitahukan jalur pendakian, dan jalur penyelamatan serta memberi informasi kepada masyarakat setempat sekiranya ada aktivitas Gunung Merapi yang membahayakan.

Peneliti akan memberikan batasan pada kajian yang ingin diteliti, maka berdasarkan fokus penelitian tersebut, pertanyaan penelitian adalah sebagai berikut: (1). Bagaimana pemahaman masyarakat sekitar Gunung Merapi Prov. D.I.Yogyakarta dan Badan Geologi KESDM mengenai Komunikasi Mitigasi Bencana?; (2). Bagaimana upaya Badan Geologi KESDM dalam melakukan Komunikasi Mitigasi Bencana berkaitan dengan kepercayaan lokal masyarakat sekitar Gunung Merapi Prov. D.I.Yogyakarta?; dan (3). Bagaimana Pola Komunikasi Mitigasi Bencana yang dilakukan Badan Geologi KESDM berkaitan dengan kepercayaan lokal masyarakat sekitar Gunung Merapi Prov D.I.Yogyakarta?

\section{METODE PENELITIAN}

Di dalam penelitian ini, peneliti menggunakan teori interaksionisme simbolik untuk melihat bagaimana Badan Geologi KESDM dan masyarakat sekitar Gunung Merapi memaknai simbol (symbol) bencana yang ada, diproses dalam pikiran (mind) yang mendorong diri (self) untuk melakukan interaksi melalui masyarakat (society). Begitu pula teori interaksi simbolik terjadi bisa diketahui dari pemaknaan masyarakat sekitar Gunung Merapi akan komunikasi mitigasi bencana yang dilakukan oleh Badan Geologi dalam bentuk sosialisasi. Apakah masyarakat memaknai interaksi yang dilakukan Badan Geologi itu atau tidak. Interaksi pada komunikasi yang dilakukan Badan Geologi pada masyarakat sekitar Gunung Merapi menimbulkan makna yang ditunjukkan melalui simbol dan menghasilkan pemaknaan dari masyarakat itu sendiri untuk kepentingan mitigasi bencana geologi.

Intinya teori interaksi simbolik menerangkan tentang konsep diri. Bukan terstrukturkan, tetapi begitu cair. Bagaimana kita memandang diri kita berdasarkan interaksi kita dengan orang lain, bisa berubah-ubah, ada konsep diri kita yang relatif permanen, ada yang tidak. Dalam kaitannya dengan komunikasi mitigasi bencana, bagaimana masyarakat sekitar Lereng Merapi melihat diri sendiri dalam konteks komunikasi mitigasi bencana. Bagaimana posisi dia sebagaimana simbol-simbol alam yang dia lihat. Orang bertindak bukan berdasar stimulus. Termasuk penggunaan bahasa lokal dan istilah-istilah khusus mengenai bencana meletus. Bagaimana mereka memandang Juru Kunci dan dikaitkan dengan diri mereka.

Berkaitan dengan teori interaksi simbolik, peneliti akan meneliti makna-makna simbolik yang muncul dari hasil interaksi Badan Geologi dengan masyarakat sekitar Gunung Merapi dikaitkan dengan kepercayaan lokal dalam hal mitigasi bencana Gunung Merapi. Dengan unsur kepercayaan yang sangat kuat akan nilai tradisi, maka komunikasi mitigasi bencana yang akan disampaikan oleh Badan Geologi harus memakai simbol-simbol yang dimengerti oleh masyarakat pedesaan di sekitar Gunung Merapi. Bagaimana tindakan masyarakat dianggap sebagaimana makhluk kreatif, mereka bertindak terhadap simbol-simbol yang dikemas dalam kepercayaan lokal yang mereka anut. Sehingga pesan akan lebih mudah dipahami dan dilaksanakan seperti yang dikehendaki oleh pemerintah untuk mewujudkan tujuan dari mit- 
igasi bencana.

Jenis penelitian yang digunakan adalah studi kasus. Karena keunikan yang dimiliki oleh Gunung Merapi dengan kepercayaan masyarakat akan tradisi yang kuat, lekat dengan unsur-unsur mitologi. Keberadaan Kasultanan Yogyakarta dan juru kunci Gunung Merapi merupakan kepercayaan lokal yang menjadi daya tarik lain dari Gunung Merapi. Daya tarik yang juga menjadi kunci dari permasalahan komunikasi bencana, ketika terjadi kekhawatiran apabila masyarakat lebih mengutamakan adat yang mereka pegang daripada anjuran dari Pemerintah.

Lokasi penelitian dipilih berdasarkan wilayah yang termasuk Kawasan Rawan Bencana (KRB) yaitu kawasan yang berpotensi tinggi terkena dampak langsung dari erupsi Gunung Merapi. Selain itu, lokasi tersebut merupakan tempat tinggal Juru Kunci Gunung Merapi dan juga petilasan Mbah Maridjan yaitu di Desa Umbulharjo Kecamatan Cangkringan Provinsi Daerah Istimewa Yogjakarta.

\section{HASIL DAN PEMBAHASAN}

Dari hasil penelitian di lapangan, terdapat pemahaman yang hampir sama pada masyarakat sekitar Gunung Merapi dalam memandang arti dari Komunikasi Mitigasi Bencana. Dalam segi istilah mereka tidak mengerti, tetapi secara substansi, mereka memahami apa itu komunikasi mitigasi bencana. Pemahaman didapat masyarakat dari berbagai aspek yaitu pengertian, kesadaran, kognisi, pengetahuan dan signifikansi. Penjabaran pemahaman masyarakat sekitar Gunung Merapi dan Badan Geologi KESDM mengenai Komunikasi Mitigasi Bencana menunjukkan bahwa kemampuan mayoritas narasumber hampir sama dalam menangkap maksud dari Komunikasi Mitigasi Bencana. Selain merupakan pemberian informasi mengenai kondisi Gunung Merapi juga merupakan pemberian informasi mengenai tindakan apa yang harus dilakukan oleh masyarakat.

Melalui hasil wawancara, pemahaman masyarakat sekitar Gunung Merapi Prov.D.I. Yogyakarta dan Badan Geologi mengenai Komunikasi Mitigasi Bencana antara lain: (1). Pemberian informasi tentang kondisi aktivitas gunung dan erupsi gunung; dan (2). Pemberian informasi tentang tindakan yang harus dilakukan oleh masyarakat yaitu: Normal, Waspada, Siaga, Awas dan Mengungsi.

Pemberian informasi oleh pemerintah dalam hal ini Badan Geologi KESDM kepada masyarakat sekitar Gunung Merapi berdasarkan kejadian erupsi dalam waktu yang hampir berdekatan (2006 ke 2010) dapat mereka terima melalui beberapa jenis media yaitu: (1). Teknologi Komunikasi (Sirine, SMS, Telepon, Radio Komunikasi Bergerak/HT, social media); (2). Gejala Alam (Suara Gemuruh Merapi, Binatang berlarian); (3). Komunikasi dari mulut ke mulut (Word of Mouth); dan (4). Pengumuman melalui mushola dan mesjid dari Kepala Dukuh (aparat pemerintahan desa)

Dari hasil penelitian yang dilakukan peneliti, bisa dilihat bahwa Komunikasi Mitigasi Bencana yang disampaikan oleh Badan Geologi KESDM sebagai komunikator dapat dipahami oleh masyarakat sebagai komunikan.Hanya yang harus diantisipasi adalah media yang dipercayai oleh masyarakat untuk menyebarluaskan informasi mengenai Komunikasi Mitigasi Bencana.

Bagaimana upaya Badan Geologi untuk meningkatkan partisipasi masyarakat dalam menghadapi bencana erupsi Gunung Merapi yaitu dengan melakukan sosialisasi dan simulasi (pelatihan) bencana. Di lain pihak, Badan Geologi juga melakukan upaya mengoptimalkan peran Juru Kunci. Juru Kunci sebagai abdi dalem Keraton Yogyakarta yang tugas utamanya sebagai pelestari kebudayaan dimanfaatkan untuk menjadi perantara antara keilmuan yang dimiliki oleh Badan Geologi dengan kepercayaan lokal yang dimiliki masyarakat. Dengan kepercayaan masyarakat akan hal yang mistis melingkupi Merapi dengan Juru Kunci sebagai simbol, Juru Kunci dapat membantu Badan Geologi dengan melakukan pendekatan khusus kepada masyarakat. Memberikan informasi kepada Badan Geologi apabila ada tanda-tanda peningkatan Merapi secara visual sebaliknya memberikan informasi terkini dari Badan Geologi kepada masyarakat.

Upaya Badan Geologi KESDM ketika melakukan Komunikasi Mitigasi Bencana kaitannya dengan kepercayaan lokal masyarakat sekitar Gunung Merapi Prov. D.I Yogyakarta diantaranya sebagai berikut: (1). Upaya pen- 
ingkatan partisipasi masyarakat oleh Badan Geologi melalui sosialisasi (penyuluhan) dan simulasi bencana (pelatihan); serta (2). Upaya peningkatan optimalisasi peran Juru Kunci yaitu dengan cara formal (pembinaan) dan informal (kunjungan).

Dalam sosialisasi terdapat proses komunikasi yang nyata. Adanya interaksi antara individu untuk saling memberikan informasi dari lingkungannya yang bisa memberikan pengetahuan baru dan membentuk konsep diri yang baru. Dengan memahami orang lain dan lingkungan lebih baik lagi, maka akan membuat kita mengerti bagaimana seharusnya berpikir dan bertindak. Sosialisasi mengenai mitigasi bencana mampu menghubungkan dua pihak. Antara pemerintah yaitu Badan Geologi dengan masyarakat sekitar Gunung Api. Adanya proses pertukaran informasi, membuat interaksi kedua belah pihak mampu menjadikan keduanya lebih baik lagi.

Produk penting dari sosialisasi adalah self/ diri. Dalam rangka melakukan interaksi dengan orang lain, maka seseorang akan mengembangkan keunikan dalam hal perilaku, pemikiran dan perasaan yang secara bersama-sama akan membentuk self. Menurut tradisi Interaksionisme Simbolik Rizer dan Goodman (2003) yang dikutip oleh Bajari, pembentukan makna pada individu tidak terlepas dari aspek-aspek yaitu: (1) kemampuan manusia dalam berpikir; (2) kemampuan berpikir dibentuk oleh interaksi sosial; (3) manusia mempelajari arti dan simbol dalam interaksi sosial, yang memungkinkan mereka menggunakan kemampuan berpikir mereka yang khusus; (4) makna dan simbol memungkinkan manusia melanjutkan tindakan khusus dan berinteraksi; (5) manusia mampu mengubah arti dan simbol yang mereka gunakan dalam tindakan dan interaksi berdasarkan penafsiran mereka terhadap situasi; (6) manusia mampu membuat kebijakan modifikasi dan perubahan; dan (7) pola tindakan dan interaksi yang saling berkaitan akan membentuk kelompok dan masyarakat. (Bajari, 2011: 88).

Apabila diterapkan pada upaya Badan Geologi memberikan informasi mitigasi bencana, dapat dijelaskan bahwa sosialisasi yang dilakukan oleh Badan Geologi merupakan pengembangan kemampuan berpikir masyarakat lereng Merapi. Dengan adanya proses komunikasi dua arah yang dinamis, membuat masyarakat sebagai individu mampu mengembangkan cara berpikirnya untuk memahami lingkungan dan mengantisipasinya demi keselamatan mereka.

Dalam proses sosialisasi, Badan Geologi memberikan pengetahuan kepada masyarakat mengenai informasi terkini Merapi, antisipasi dan persiapan masyarakat terhadap kemungkinan ancaman bahaya yang akan terjadi serta cara-cara penyelamatan diri. Kata kunci dari sosialisasi adalah mengungsi. Lupakan harta benda, lupakan mitos yang mengatakan bahwa Merapi hanya terbangun saja. Segera lari dan selamatkan diri dan keluarga. Informasi inti yang dikemas dalam sosialisasi disesuaikan dengan kultur masyarakat Lereng Merapi.Apabila diterapkan pada upaya Badan Geologi memberikan informasi mitigasi bencana, dapat dijelaskan bahwa sosialisasi yang dilakukan oleh Badan Geologi merupakan pengembangan kemampuan berpikir masyarakat lereng Merapi. Dengan adanya proses komunikasi dua arah yang dinamis, membuat masyarakat sebagai individu mampu mengembangkan cara berpikirnya untuk memahami lingkungan dan mengantisipasinya demi keselamatan mereka.

Proses sosialisasi dalam menyampaikan pesan dan simbol akan menimbulkan berbagai pendapat dan makna dalam masyarakat. Menurut teori Social Expectation Theory yang dikemukakan oleh Cooley, manusia tidak sekadar sebagai individu tetapi merupakan individu dalam konteks sosial, dalam jaringan sosial, dalam masyarakat yang kompleks sehingga dia selalu merespons setiap stimulus dari luar, berarti pengaruh faktor sosial dan kultural sangat besar terhadap perilaku individu (Liliweri, 2011: 175). Masyarakat lereng Merapi sebagaimana individu lainnya secara psikologis memproses tindakan yang akan dilakukan di dalam dirinya terlebih dahulu, dia akan memilih tindakan apa yang diambil ketika terjadi peningkatan aktivitas Gunung Merapi. Kemudian dia akan mempertimbangkan apa yang orang lain harapkan untuk dia lakukan. Apakah sama-sama mengungsi atau hanya berdiam diri dan menunggu instruksi dari Juru Kunci sebagaimana biasanya.

Badan Geologi bisa melakukan Komunikasi Mitigasi Bencana tanpa terbentur oleh tradisi, bisa seiring sejalan dan saling menguatkan. Peningkatan partisipasi masyarakat dan 
optimalisasi peran Juru Kunci menjadi upaya Badan Geologi dalam mengembangkan Komunikasi Mitigasi Bencana. Upaya Badan Geologi dalam komunikasi mitigasi bencana selain peningkatan partisipasi masyarakat juga optimalisasi peran Juru Kunci. Meski Juru Kunci sekarang lebih modern dari segi pendidikan dan cara berpikir, tapi tidak dapat dipungkiri akan kuatnya tradisi jawa. BPPTKG Badan Geologi yang dilibatkan dalam pemilihan Juru Kunci seharusnya tidak cukup berhenti sampai di situ. Juru Kunci bisa diajak sebagai rekan kerja Badan Geologi. Keberadaannya bisa dimanfaatkan sebagai agen sosialisasi yang bertugas untuk menyampaikan informasi ilmiah dari Badan Geologi. Optimalisasi Juru Kunci ini bisa dalam bentuk pembinaan khusus yaitu pelatihan mengenai proses terjadinya erupsi, pengenalan istilah-istilah teknis kebencanaan dan informasi lainnya yang berkaitan. Pembinaan juga bisa berupa kunjungan informal baik dari petugas pengamat Gunung Merapi maupun dari pejabat BPPTKG yang terkait.

Kepercayaan lokal masyarakat sekitar Gunung Merapi dalam hal ini kepercayaan mereka akan tradisi dengan memegang teguh segala ritual tradisional seharusnya tidak menjadi halangan bagi Badan Geologi dalam melakukan upaya Komunikasi Mitigasi Bencana. Apabila diaplikasikan dalam komunikasi mitigasi bencana sesuai hasil penelitian tergambar adanya dua jenis pola komunikasi. Pola komunikasi berstruktur yaitu pemberian informasi mengenai mitigasi bencana secara terstruktur dari atas ke bawah. Badan Geologi sebagai pemberi rekomendasi keadaan Gunung Merapi yang menyampaikan kepada Pemda setempat dalam hal ini para Bupati. Selanjutnya oleh Bupati informasi tersebut disampaikan kepada para Kepala Desa. Kepala Desa melakukan koordinasi dengan para Kepala Dukuh sebagai ujung tombak pemerintah.Kemudian disebarluaskan melalui pengumuman di mesjid oleh Ketua RW ataupun Ketua RT dan juga langsung mendatangi lokasi warga untuk memberitahukan kondisi terkini Gunung Merapi.

Pola komunikasi terstruktur dalam penelitian ini berdasarkan pada kebutuhan tindakan spesifik yang harus dilakukan. Struktur di sini merupakan konstruksi unik yang mungkin tidak akan berlangsung tanpa adanya interaksi. (Pace,
2010: 19). Meski pola komunikasi terstruktur cenderung dilakukan dari atas ke bawah (top down) namun sebetulnya melalui sarana simbolik, pemerintah dan rakyat mengembangkan secara bersama-sama.

Pola komunikasi yang kedua yaitu pola komunikasi melalui media mengenai adanya kesetaraan antara Badan Geologi, Pemda, LSM dan masyarakat dalam alur pemberian dan penerimaan informasi. Media berfungsi sebagai perantara informasi yang dipercaya oleh masyarakat. Media yang berperan bermacam-macam. Seperti media cetak, media elektronik, media sosial, telepon, sms, dan terakhir Handy Talkie. Handy Talkie adalah alat komunikasi dua arah yang menggunakan frekuensi VHF (Very High Frekuensi) dan UHF (Ultra High Frekuensi) bersifat portable dan bisa dibawa ke mana saja. Handy Talkie sangat berperan besar ketika di lapangan dalam kondisi suasana mulai genting.

Di Desa Umbulharjo khususnya, perangkat ini cukup popular digunakan. Keunggulan dari pemakaian Handy Talkie adalah hanya membutuhkan arus listrik dan bisa berhubungan langsung dengan pemakai Handy Talkie lain pada frekuensi yang sama, tidak perlu membayar biaya/tarif seperti pada telepon genggam. Mengingat pada kejadian bencana di manapun termasuk bencana erupsi Merapi, beberapa penyedia jasa layanan telekomunikasi (telepon) tidak bisa aktif. Listrik PLN pastilah akan mati sehingga menyulitkan untuk mendapatkan informasi terkini. Dalam keadaan genting seperti itulah, Handy Talkie yang mampu menyebarkan informasi penting dari dan kepada masyarakat. Kelebihannya bisa didengar oleh siapapun yang Handy Talkienya memiliki frekuensi sama. Sehingga biasanya anggota Lembaga Swadaya Masyarakat apapun akan mengambil keutamaan Handy Talkie untuk mengurangi resiko dari bencana erupsi. Dengan disampaikannya informasi melalui Handy Talkie maka masyarakat akan cepat mengambil tindakan pencegahan yang diperlukan.

Pola komunikasi mitigasi bencana, baik yang terstruktur maupun yang melalui media akan menghasilkan komunikasi yang efektif apabila semua pihak terkait mau bekerja sama. Dan harus diakui, keberadaan Juru Kunci sebagai kepercayaan lokal masyarakat Jawa khususn- 
ya Yogyakarta tidak bisa diabaikan begitu saja. Adanya realitas yang tidak nampak dalam kehidupan kita bahkan sudah menjadi kajian akademik. Menurut Prof. Engkus Kuswarno dalam tulisannya "Komunikologi Hado" dalam buku Komunikasi Kontekstual (Bajari, 2011: 8), adanya salah satu cabang filosofi yaitu metafisika yang bertujuan untuk memahami hakikat suatu realitas, baik yang tampak maupun yang tidak tampak (visible or invisible). Metafisika komunikasi apabila dikaitkan dengan filosofinya, adanya upaya memahami komunikasi melampaui batas antar manusia. Hubungan manusia dengan alam, komunikasi yang terjadi tidak hanya pada kehidupan manusia saja ( $h u$ man communication), tetapi juga pada segala macam kebendaan di muka bumi ini. Termasuk komunikasi dengan Sang Pencipta bahkan dengan dunia gaib atau mistis.

Selaras dengan yang dikatakan oleh Kepala Desa Umbulharjo, bahwa untuk menjadi Juru Kunci itu tidak mudah, adanya lakon-lakon yang tidak setiap orang mampu melakukannya. Istilah yang dia sebut sebagai komunikasi meditasi. Ketika dialog yang dilakukan oleh seorang Juru Kunci kepada Merapi atau penunggu Merapi atau kepada Tuhan YME, saat itulah komunikasi berperan melampaui ambang batas pikiran manusia. Badan Geologi sebagai instansi teknis yang mengurusi Merapi tidak boleh tutup mata dengan fenomena ini, bahkan seharusnya bisa mengambil sisi baik. Adanya dunia metafisis bisa disandingkan dengan keilmuan, selaras bersama-sama tanpa saling meniadakan satu sama lain.

Memahami metafisis akan membuat manusia kembali untuk berpikir mengenai moral. Adanya pendekatan yang berbeda dalam mitigasi bencana bagi masyarakat yang unsur mistisnya masih sangat kuat. Pendekatan keagamaan akan lebih tepat dalam menyampaikan informasi mitigasi bencana. Terkait dengan pertanyaan penelitian nomor 2 mengenai upaya Badan Geologi, pola komunikasi yang dilakukan hendaknya menggandeng unsur kepercayaan lokal.

\section{SIMPULAN}

Berdasarkan paparan yang telah disajikan, maka dapat ditarik beberapa simpulan, sebagai berikut: (1). Masyarakat sekitar Gunung Mera- pi yaitu yang berdomisili di Desa Umbulharjo Kecamatan Cangkringan Prov. D.I. Yogyakarta memahami istilah Komunikasi Mitigasi Bencana sebagai pemberian informasi mengenai kondisi Gunung Merapi dan pemberian informasi mengenai tindakan yang harus dilakukan oleh masyarakat. Peneliti menemukan hal menarik yaitu media yang dipercaya oleh masyarakat bermacam-macam. Mulai dari teknologi komunikasi seperti telepon genggam, Handy Talkie, kemudian media yang bersumber dari simbol alam yaitu suara gemuruh, binatang berlarian dan media lainnya seperti komunikasi antar pribadi yaitu dari mulut ke mulut (word of mouth); (2). Upaya yang dilakukan oleh Badan Geologi dalam melakukan Komunikasi Mitigasi Bencana terhadap masyarakat sekitar Gunung Merapi harus memperhatikan unsur kepercayaan lokal yang masih erat dianut masyarakat.Upaya tersebut terbagi ke dalam dua kategori yaitu adanya upaya peningkatan partisipasi masyarakat oleh Badan Geologi dalam hal ini sosialisasi dan simulasi bencana atau pelatihan. Upaya lainnya yaitu peningkatan optimalisasi peran Juru Kunci yaitu secara formal (pembinaan) dan informal (kunjungan); dan (3). Pola Komunikasi Mitigasi Bencana yang dilakukan Badan Geologi KESDM terkait dengan kepercayaan lokal masyarakat sekitar Gunung Merapi dapat dikategorikan dalam dua jenis pola komunikasi yaitu pola komunikasi terstruktur dan pola komunikasi melalui radio komunikasibergerak (Handy Talkie). Adanya kesadaran dari kedua belah pihak baik Badan Geologi maupun masyarakat sekitar Gunung Merapi untuk terus bersama-sama memperbaharui informasi mengenai aktivitas Merapi. Informasi terkini yang melalui proses teknologi lmu kebumian tidak hanya mengandalkan gejala alam saja dan kepercayaan lokal dalam hal ini wangsit atau mimpi dari Merapi. Adanya proses komunikasi dua arah saling timbal balik baik pada pola komunikasi terstruktur maupun pola komunikasi melalui media radio komunikasibergerak (Handy Talkie).

Sedangkan saran yang perlu diperhatikan baik oleh Badan Geologi maupun oleh pihak terkait yaitu: (1) Badan Geologi KESDM perlu mengkaji lebih dalam mengenai Komunikasi Mitigasi Bencana. Komunikasi Mitigasi Bencana diperlukan dalam rangka peningka- 
tan kapasitas masyarakat di dalam menghadapi dan menanggulangi bencana geologi untuk menghindari ketidakselarasan dalam penerimaan informasi. (2) Badan Geologi KESDM diharapkan meningkatkan frekuensi sosialisasi dan simulasi bencana langsung pada masyarakat tingkat bawah, tidak hanya mengundang perwakilan dari aparat pemerintah saja. Sebaiknya Badan Geologi mengundang Juru Kunci Merapi untuk diberikan pelatihan khusus berbeda dengan masyarakat biasa untuk diberikan materi mengenai istilah-istilah teknis kebencanaan, sehingga Juru Kunci bisa menjadi agen sosialisasi bagi masyarakat. (3) Badan Geologi diharapkan untuk lebih merangkul keberadaan Lembaga Swadaya Masyarakat dan organisasi-organisasi radio komunikasi bergerak di sekitar Merapi. Mereka bisa membantu mengatasi keterbatasan jangkauan informasi bagi masyarakat yang mengalami kendala dalam mengakses informasi terkini.

\section{DAFTAR PUSTAKA}

Bajari, A. (2011). Komunikasi kontekstual. Bandung: Remaja Rosdakarya.

Haddow, G. D. (2008). Disaster communications: in a changing media world. UK: Butterworth Heinemann.

Liliweri, A. (2011). Komunikasi: serba ada, serba makna. Jakarta: Kencana.

Pace, R. W. \& Faules D. F. (2010). Komunikasi organisasi. Bandung: Remaja Rosdakarya.

Santosa, I. B. (2012). Spiritualisme jawa. sejarah, laku dan intisari ajaran. Yogyakarta: Memayu Publishing.

BBC Indonesia. (2011, 2 November). Diakses 7 Maret 2013 melalui www.bbc.indonesia. co.uk/indonesia/ 